\title{
Effects of Phonics Charts on Senior Secondary School Students' Achievement in Oral English in Edu, Kwara State
}

\author{
Muritala Imam Suleiman ${ }^{1}$, Muhammed Adam ${ }^{2}$ \\ 1,2 Lecturers in Department of General Studies, Kwara State College of Education, Technical, Lafiagi, \\ Nigeria \\ Email: suljurist@gmail.com
}

\begin{abstract}
The phenomenon of poor performance in internal and external examinations among Nigerian students, especially, those in the secondary schools, is a matter that has become a source of concern to stakeholders in the education sector in the country. This study therefore investigated the effects of phonics charts on senior secondary school students' achievement in oral English in Edu, Kwara State. Three objectives and corresponding research questions guided the study. Two hypotheses postulated were tested at 0.05 alpha levels. The quasi-experimental design was adopted using the non-randomised pre/posttest groups design. The population for this study was all senior secondary school students in Edu, Kwara State. The target population for this study was all SSII students in public schools in Lafiagi Emirate, 87 students were sampled in their intact classes. The Oral English Achievement Test (OEAT) with a reliability coefficient of 0.69 was used to gather the data for the study. The data collected were analysed using descriptive and inferential statistic methods-mean and standard deviation and the Analysis of Covariance (ANCOVA).The findings obtained from this study revealed that the general achievement level of students (both the experimental and control groups) in Oral English was low in the pre-test. However, in the post-test, the general achievement level of the students that were taught with phonics charts in Oral English was relatively high (32.00), while that of students taught with the conventional method was average (24.78). there was a statistically significant effect of phonics charts on senior secondary school students that were taught Oral English with Phonics charts and those taught without it in Edu, Kwara State $\left(F_{(1,82)}=7.039, p<0.05\right)$ Based on the findings of the study, it was recommended among others that necessary attention should be accorded use of phonics charts in the secondary schools, especially for teaching Oral English. Teachers, textbook writers and curriculum planners should emphasis the use of phonics charts for teaching and learning of Oral English in Secondary schools in Kwara State.
\end{abstract}

Keywords: phonics charts; oral English achievement

\section{Introduction}

Language sounds are just part of the totality of sounds in the universe. Oral English Language was introduced in 1977 as part of English language paper in the teachers' grade II certificate examination. This component of English language constitutes a sub-section in English language paper in the West African Examinations Council (WAEC) and the National Examinations Council (NECO). It has also received prominence in English language syllabus, especially in our secondary schools. Consequently, learners of English language-as-a-second language are mostly faced with the problem of oral proficiency in terms of appropriate pronunciation of English sounds (phonemes). The provision of adequate instruction in Oral English Language class is regarded as a sine qua non to the acquisition of the basic skills of the language (Joshua \& Lynda, 2014).

Phonics heightens the relationship between the letters in written language and the sounds in spoken language. Successful phonics instruction is dependent upon the development of phonemic awareness. To perform phonics skills requires the understanding of alphabetic principle 
(Lai, 2003). The Federal Government of Nigeria (2011) posited that phonics allows students to have a guess at the spelling of a word, making reading and writing a simpler task. It also allows teachers to practice pronunciation in minimal pair activities. A good higher-level example would be practising changes in sounds due to adding a final 'e' (pope/pop; pipe/pip; tap/tape).

Good (1976) defined achievement as accomplishment or proficiency of performance in a given skill or body of knowledge. The knowledge attained or skills developed in school subjects are usually developed by teachers. Brown and Hackett (2000) posited that academic achievement is a key mechanism through which adolescents learn about their talents, abilities and competencies which are important in developing career aspiration. Karthigeyen and Nirmala (2012) observed that academic achievement has become an index of students' future in this highly competitive world. It has been one of the most important goals of the educational process. Ibrahim and Baba (2008) asserted that students' achievement may be accessed through a variety of instruments, such as tests, class work, assignments, homework, quizzes, orals and interviews. Students' achievement is one of the variables to be assessed in this study before and after the experimental group exposed to the treatment.

In view of the central position of English language in the academic, social, and economic well-being of Nigerian students, poor achievement in English is a setback, not only to the students but also to the society. Deficiency in grammar, lexis and structure and spoken English can be a great limitation to anyone that needs to survive in an environment where English is the tool of politics, education, commerce, religion, and information (Omojuwa, 2014).

The achievement of students in English language on the basis of gender is another essential part of this study. Admittedly is the fact that women are hypercorrect in speech. They also use succulent words while their male counterparts are coarse and husky. Gender is the term used when referring to men and women, boys and girls as social groups. Therefore, gender is a socialpsychological concept. It is the different cultural and social roles which societies around the world ascribed to male and female in order to depict the differences between them (Bibire, 2010; Mostafa,2019; Tesfaye and Desalegn,2019).

Parley (1972) asserted that no differences in general intelligence have been reported between the sexes. Although, there are some evidences that males score higher than females in Mathematics ability. In terms of difference in aptitude, boys were found superior to girls not only in physical strength but also in speed and coordination of movement. Girls on the other hand, are superior to boys in manual dexterity. With regards to verbal aptitudes, girls have been found to be superior to boys in every respect and this superiority is observed from infancy through adulthood.

Buffery and Grey (1972) posited that there has been contention that girls perform better on verbal tasks because of the left brain hemisphere, which is important for language acquisition develops dominance in girls at early age than in boys. From infancy to adulthood, females express themselves in words more readily and skillfully than males. As observed by Nwobia (2007), the difference between male and female are visualised in varied ways. Male exhibits verbal skills which are different from that of female, likewise the voice pitch of the females are usually higher than that of the males. Nwobia also reported that in reading ability, females tend to read better and more fluent than males. However, Ogunwole (2014) observed that gender has no significant effect on students' performance in essay writing.

Adeyemi (2010) researched a comparative study of students' academic performance in public examination in secondary schools in Ondo and Ekiti States, Nigeria. It was found that the 
performance of students in Junior Secondary Certificate (JSC) and the Senior Secondary Certificate Examination (SSCE) was low. Ajayi's (2012) finding however revealed a fluctuating trend of mass failure of students in WASSCE 2003 - 2010. It was reported that students lost substantial marks in the aspect of Test of Orals (WAEC, 2012). The causes of the poor performance may include: poor reading culture, illegible handwriting and poor spellings, students' inability to write effectively, poor instructional methodology, among others (Ogunbanwo, 2014).

Henterly (2002) conducted a quasi-experimental study with 38 kindergarten students to determine if daily phonemic awareness activities impacts students' developmental spellings. The treatment and control group received similar instruction during September to February of their kindergarten year on alphabet recognition and symbol-sound correspondence. Students in the treatment group received additional training in phonemic awareness over a five month period. The post-test measures found that the students in the treatment group scored significantly higher than the control group on assessment measures.

However, Kutigi, Gambari and Gana (2010) carried out research on the effect of digital audio instructional package on the performance of senior secondary school students in Oral English in Minna, Nigeria. Their findings revealed that there were significant differences in the mean achievement scores of students taught Oral English using digital audio instructional package and those taught with the lecture method.

Kodae and Laohawiriyanon (2011) also examined the efficacy of intensive explicit phonics instruction on reading and spelling attainment of Thai English language learners with reading difficulties. Forty one fifth graders in a primary school in Thailand participated in this study. The training was given one hour per day for 8 weeks. A one group post-test and retention test design was used to collect data. The results suggested that both middle and low achievers benefited from the programme specifically in relation to word recognition ability.

From the foregoing, it could be observed that none of the previous research works cited herein paid attention to the effect of phonics charts on senior secondary schools students' achievement in Oral English, especially in Edu, Kwara State. This has therefore created a researchable gap, part of which this study intends to fill.

The main purpose of this study was to investigate the effect of phonics charts on senior secondary school students' achievement in Oral English in Edu, Kwara State. Specifically, the study looked into:

a. the general level of achievement of senior secondary school students in Oral English in Edu, Kwara State.

b. the effect of phonics charts on senior secondary school students achievement in Oral English in Edu, Kwara State.

c. the interactive effect of phonics charts and gender on the achievement of senior secondary school students in Oral English in Edu, Kwara State.

\section{Research Method}

The quasi-experimental research design was adopted in this study. This design is a nonrandomised pre/post-test groups (experimental and control groups) design and was used in this study to determine the effect of phonics charts on senior secondary school students' academic achievement in Oral English. The performance of the pre-test was used to obtain the entry 
behaviour or previous knowledge of the groups involved in the study. The post-test was used to assess the knowledge gained after the treatment.

The design involved students from intact classes. The experimental group was taught with the use of phonics charts, while the control group was taught without it. In this study, the design entails the 2x2 modes implying the teaching at two levels Experimental (with phonics charts) and control (without phonics charts); and gender (Male and Female)

Table 1: 2 x 2 Design on the Effect of Phonics Charts

\begin{tabular}{lcccc}
\hline GROUPS & Pre-test & Gender & Treatment & Post-test \\
\hline $\begin{array}{l}\text { Experimental Group } \\
\text { (With phonics charts) }\end{array}$ & $\mathrm{O}_{1}$ & $\mathrm{M} / \mathrm{F}$ & $\mathrm{X}$ & $\mathrm{O}_{2}$ \\
$\begin{array}{l}\text { Control Group } \\
\text { (Without phonics charts) }\end{array}$ & $\mathrm{O}_{3}$ & $\mathrm{M} / \mathrm{F}$ & - & $\mathrm{O}_{4}$ \\
\hline
\end{tabular}

Keys:

$\mathrm{O}_{1}$ and $\mathrm{O}_{3} \quad$ - represent pre-test.

$\mathrm{M} / \mathrm{F} \quad-$ represents male and female.

(X) $\quad-$ represents phonics charts

$(-) \quad-$ represents without phonics charts.

$\mathrm{O}_{2}$ and $\mathrm{O}_{4} \quad-$ represent post-test.

The population for this study comprised all the Senior Secondary School students in Edu, Kwara State. The target population was all (SSS 2) students in public senior secondary schools in Lafiagi Emirate. Senior Secondary School (SSS 2) students at intact classes in public schools were sampled using multistage sampling technique.

At the 1st stage, simple random sampling technique was used to select two public schools (one for experimental and the other for control group) within Lafiagi Emirate, Kwara State. At the 2nd stage, purposive sampling was used to select SSS2 students at intact classes. These students were selected because they were at the stage/period (SSS II class) when they started to be introduced to the aspects that are more complex in oral English curriculum which required to be taught with phonics charts for effective teaching and learning to take place.

At intact class, forty six (46) students constituted the experimental group while forty one (41) students formed the control group thereby making a total number of eighty seven (87) students that were sampled for this study.

The main instrument used for data collection for the study was Oral English Achievement Test (OEAT). The instrument contained two sections. Section A was used to elicit the background information of the respondents; while section B consisted of 50 items drawn from past WAEC question papers, multiple choice objective items. Each item was scored dichotomously. Topics were from vowel sounds. Oral English Achievement Test (OEAT) was used for pre-test and posttest exercise.

To ascertain the validity of the research instrument, the instrument was given to the researcher's supervisor and two experts in the English language education, University of Ilorin to scrutinise and determine the suitability and the instructional packages of the instrument while the final draft was approved by the researcher's supervisor. All corrections made by these experts enabled the researcher to eliminate and reconstruct some items in the instrument. 
Afterwards, this instrument was administered to a set of 20 students that were not part of the participating schools which also enabled the researcher to identify, reconstruct and rule out some items that seemed to be too difficult or too easy in Oral English Achievement Test (OEAT).

The reliability of the instrument was carried out using split half method of reliability. Then their scores in the two halves were subjected to reliability using Cronbach Alpha Method and the reliability coefficient of 0.69 was therefore obtained. This indicated that the instrument is reliable.

\section{Research Question 1}

What is the general level of achievement of senior secondary school students in Oral English in Edu, Kwara State?

Table 2. Achievement of Students Taught Oral English with Phonics Charts and Those Taught without phonics chart before and after the Treatment in Edu, Kwara State

\begin{tabular}{llcrrrc}
\hline Groups & & $\begin{array}{c}\text { Mean } \\
\text { Score }\end{array}$ & S.D. & $\begin{array}{r}\text { Min } \\
\text { Score }\end{array}$ & $\begin{array}{c}\text { Max } \\
\text { Score }\end{array}$ & Remark \\
\hline \multirow{2}{*}{ Experimental } & Pre-test & 13.38 & 3.64 & 7.00 & 23.00 & Low \\
& Post-test & 32.00 & 3.77 & 20.00 & 38.00 & High \\
Control & Pre-test & 11.81 & 2.97 & 6.00 & 18.00 & Low \\
& Post-test & 24.78 & 3.16 & 15.00 & 31.00 & Average \\
\hline
\end{tabular}

As revealed in Table 3, the mean scores 13.38 and 11.81 were obtained in the pre-test for the experimental and control groups respectively, while the mean scores 32.00 and 24.78 were obtained in the post-test for the experimental and control groups, respectively. This implies that the general achievement level of students (both the experimental and control groups) in Oral English was low in the pre-test. However in the post test, the general achievement level of students that were taught Oral English with phonics charts was relatively high (32.00) while that of students taught without was of average (24.78).

Hypothesis One: There is no significant effect of phonics charts on senior secondary school students' achievement in Oral English in Edu, Kwara State.

Table 3: Analysis of Covariance Showing the Effect of Phonics Charts on Senior Secondary School Students' Achievement in Oral English in Edu, Kwara State

\begin{tabular}{lrrrrrc}
\hline Source & $\begin{array}{c}\text { Type III Sum } \\
\text { of Squares }\end{array}$ & df & $\begin{array}{c}\text { Mean } \\
\text { Square }\end{array}$ & F & Sig. & Remark \\
\hline Corrected Model & $7070.221^{\mathrm{a}}$ & 2 & 3535.111 & 284.375 & .000 & \\
Intercept & 2594.150 & 1 & 2594.150 & 208.682 & .000 & $\mathrm{HO}_{1}:$ \\
Pretest & 14.055 & 1 & 14.055 & 1.131 & .291 & Rejected \\
Treatment & 6554.762 & 1 & 6554.762 & 527.286 & .000 & \\
Error & 1044.216 & 84 & 12.431 & & & \\
Total & 59288.000 & 87 & & & & \\
Corrected Total & 8114.437 & 86 & & & & \\
a. R Squared $=.871$ (Adjusted R Squared $=.868)$ & & & & \\
\hline
\end{tabular}

$*$ Significant at $\mathrm{p}<0.05$

Result in Table 4 reveals that the F-value of 527.286 is obtained with a p-value of 0.00 computed at 0.05 alpha level. Since the p-value (0.00) is less than alpha level (0.05), the null hypothesis one is not accepted. Thus, there is a statistically significant effect of phonics charts on 
senior secondary school students' achievement in Oral English in Edu, Kwara State $\left(\mathrm{F}_{(1,84)}=\right.$ 527.286, $\mathrm{p}<0.05)$.

The Multiple Comparison Analysis is depicted in Table 5 to show the actual effect of the treatment on students' performance (mean difference in the achievement of those taught with Phonics Charts and those taught without).

Table 4: Pairwise Comparisons Analysis Showing the Effect of the Treatment on Students' Achievement in Oral English

\begin{tabular}{lccrccc}
\hline & & & \multicolumn{3}{c}{$\begin{array}{c}\mathbf{9 5 \%} \text { Confidence } \\
\text { Interval for Difference }\end{array}$} \\
\cline { 3 - 7 } Treatment & Mean & $\begin{array}{c}\text { Mean } \\
\text { Difference (I-J) }\end{array}$ & $\begin{array}{r}\text { Std. } \\
\text { Error }\end{array}$ & Sig. $^{\text {b }}$ & $\begin{array}{c}\text { Lower } \\
\text { Bound }\end{array}$ & $\begin{array}{c}\text { Upper } \\
\text { Bound }\end{array}$ \\
\hline Experimental $(\mathrm{I})$ & $32.00^{\mathrm{a}}$ & $7.22^{*}$ & 0.77 & 0.00 & 2.12 & 5.20 \\
Control $(\mathrm{J})$ & $24.78^{\mathrm{a}}$ & $-7.22^{*}$ & 0.77 & 0.00 & -5.20 & -2.12 \\
Grand Mean $=\mathbf{2 8 . 3 9}$ & & & & & \\
\hline
\end{tabular}

Based on estimated marginal means

* The mean difference is significant at the 0.05 level

b. Adjustment for Multiple Comparisons: Bonferroni

Table 5 reveals that students in the experimental group had higher mean score of 32.00 than those in the control group with a mean score of 24.78. This implies that students taught Oral English with phonics charts performed better than those taught without it in Oral English Achievement Test (OEAT) with mean difference of 7.22.

Hypothesis Two: There is no significant interactive effect of phonics charts and gender on the achievement of senior secondary school students' achievement in Oral English in Edu, Kwara State.

Table 5: Analysis of Covariance showing the interactive effect of phonics charts and gender on senior secondary school students' achievement in Oral English in Edu, Kwara State

\begin{tabular}{|c|c|c|c|c|c|c|}
\hline Source & $\begin{array}{l}\text { Type III } \\
\text { Sum of } \\
\text { Squares }\end{array}$ & df & $\begin{array}{r}\text { Mean } \\
\text { Square }\end{array}$ & $\mathbf{F}$ & Sig. & Remark \\
\hline Corrected Model & $7180.001^{a}$ & 4 & $\begin{array}{r}1795.00 \\
0\end{array}$ & 157.517 & .000 & \\
\hline Intercept & 1973.685 & 1 & $\begin{array}{r}1973.68 \\
5\end{array}$ & 173.198 & .000 & \\
\hline Pre-test & 27.907 & 1 & 27.907 & 2.449 & .121 & \\
\hline Treatment & 4771.136 & 1 & $\begin{array}{r}4771.13 \\
6\end{array}$ & 418.684 & .000 & \\
\hline $\begin{array}{l}\text { Gender } \\
\text { Treatment* }\end{array}$ & $\begin{array}{r}6.259 \\
80.210\end{array}$ & $\begin{array}{l}1 \\
1\end{array}$ & $\begin{array}{r}6.259 \\
80.210\end{array}$ & $\begin{array}{r}.549 \\
7.039\end{array}$ & $\begin{array}{l}.461 \\
.010\end{array}$ & \\
\hline \multicolumn{7}{|l|}{ Gender } \\
\hline Error & 934.436 & 82 & 11.396 & & & \\
\hline Total & 59288.000 & 87 & & & & \\
\hline $\begin{array}{l}\text { Corrected Total } \\
\text { a. R Squared }=.88\end{array}$ & $\begin{array}{r}8114.437 \\
\text { Idjusted R Squ }\end{array}$ & $\begin{array}{l}86 \\
e d=\end{array}$ & & & & \\
\hline
\end{tabular}


As shown in Table 6, the F-value of 80.210 is obtained with a p-value of 0.01 computed at 0.05 alpha level. Since the p-value (0.01) is less than alpha level (0.05), the null hypothesis two is not accepted. Thus, there is a statistically significant interactive effect of phonics charts and gender on senior secondary school students' achievement in Oral English. This implies that there is a significant difference in the achievement of male and female senior secondary school students that were taught Oral English with phonics charts and those taught without phonics chart in Edu, Kwara State $\left(\mathrm{F}_{(1,82)}=7.039, \mathrm{p}<0.05\right)$.

Mean scores are therefore depicted in Table 7 to show where the statistical difference lies between male and female students that were taught Oral English with Phonics Charts and those taught without it.

Table 7: Achievement of Male and Female Students Taught Oral English with Phonics Charts and those taught without

\begin{tabular}{llrrrr}
\hline Gender & Groups & Mean & Std. & \multicolumn{2}{c}{ 95\% Confidence Interval } \\
\cline { 5 - 6 } & & & Error & Lower Bound & Upper Bound \\
\hline \multirow{2}{*}{ Male } & Experimental & $30.303^{\mathrm{a}}$ & .794 & 28.582 & 31.743 \\
& Control & $26.164^{\mathrm{a}}$ & .950 & 12.775 & 17.554 \\
Female & Experimental & $33.700^{\mathrm{a}}$ & .617 & 31.795 & 34.251 \\
& Control & $23.391^{\mathrm{a}}$ & 1.301 & 12.319 & 14.904 \\
\hline
\end{tabular}

a. Covariates appearing in the model are evaluated at the following values: Pre-test $=12.7126$.

As shown in Table 7, female students in the experimental group had the higher mean score (33.700) than their male counterpart (30.303) followed by male students in the control group with the mean score 26.164 which was higher than their female counterpart. This implies that both female and male students (with the highest mean score) in the experimental group performed better than those in the control group.

\section{Discussion}

Findings from this study revealed that the general achievement level of students in Oral English was low in the pre-test. However, in the post-test, the general achievement level of students that were taught with phonics charts in Oral English was relatively high while that of students taught without it was average. This finding indicated that phonics charts strategy has a positive effect on students' achievement in words and letters relationship, and this may be due to the phonics charts that exposed students beyond conventional method thereby resulting in students' higher performance in Oral English.

Result obtained from this study showed that there was a statistically significant effect of phonics charts on senior secondary school students' achievement in Oral English in Edu, Kwara State. Students taught Oral English with phonics charts performed better than those taught without it in Oral English Achievement Test (OEAT) with the mean difference of 7.22.

Findings from this study also showed that there was a significant difference in the achievement of male and female senior secondary school students that were taught Oral English with phonics charts and those taught without it in Edu, Kwara State. Female students in the experimental group had a higher mean score $(33,700)$ than their male counterpart $(30,303)$ followed by male students in the control group with the mean score 26.164 which was higher than their female counterpart. Thus, both female and male students (with the highest mean scores) in the experimental group performed better than those in the control group. This finding is in line 
with that of Josephine and Ajiwoyu (2015) who examined the effects of gender and school location on students' achievement in English vocabulary in junior secondary schools in Akoko south education zone, Ondo State. The result of this study showed that gender had a significant effect on secondary school students' achievement in English vocabulary.

This finding is also in line with the outcome of Soki (1990) that compared the achievement scores of boys and girls in Mathematics and English language. Soki (1990) discovered that girls excelled with high scores in English language than boys. Ibitoye (1996) and Pappamitheil (2001) also found out that girls performed better than boys in English language.

\section{Conclusion}

Based on the Findings obtained from this study, it could be concluded that phonics charts strategy is an expository teaching strategy that has a positive effect on students' word recognition and pronunciation, thereby resulting in students' higher achievement in Oral English, even though female students taught with phonics charts performed better than their male counterpart. This is an indication that phonics charts has positive effect on both female and male students, but most especially on female students. proffered:

With respect to the findings obtained for this study, the following recommendations were

1. Students of English as a second language should endeavour to learn, understand and practise the correct pronunciation of English phonemes or words in order to attain oral proficiency.

2. Necessary attention should be accorded phonics charts in the secondary school setting, especially for teaching Oral English in Kwara State.

3. There is the need to give orientation to teachers and students on the significance of the course. Teachers should be encouraged to attend workshops, seminars, refresher courses and the like in order to update their knowledge and improve on their teaching methodology.

4. Government, private organisation or individuals should assist in providing necessary facilities as teaching aids such as phonics charts, television sets, radio, tape recorder, flash cards and other related facilities that will help in facilitating easier understanding of the course.

5. Provision of relevant text books on oral English should be made available to the learners either by the government or through individual's efforts.

6. The ministry of education at the state and federal level should prevail on secondary school proprietors (and the government in the case of government schools) to set up functional language laboratories.

\section{References}

Adeyemi, T.O.(2010).Predicting students' performance in senior secondary certificate examination and junior secondary certificate examinations in Ondo and Ekiti states, Nigeria. Humanity and Social Science Journal. 3(I):26-36.

Ajayi, I.A.(2012). Mass failure of students in West African senior school certificate examination in Nigeria the teachers' perspective. A paper delivered at the Clute Institute International Academic ConferenceUSA.www.cluteinstitute.com.

Bibire, A.K.(2010). Relationship between personality types students' academic performance in Islamic studies in Kwara State. Unpublished master's thesis, University of Ilorin.

Brown, S.D., Hackett. G.(2000). Contextual supports and barriers to career choice. A Social Cognitive Analysis. Journal of Counselling Psychology. 47, 36-49. 
Buffery, C.\& Grey, F. (1972). Diagnostic effects of reading disorder. New York, Cambridge University Press.

Federal Government of Nigeria (2011).Phonics and Oral English; Federal teachers' scheme capacity building. Universal Basic Education Commission. Abuja.

Good, C.V. (1976). Dictionary of education. New York: Mcgraw-Hill.

Henterly, A.M. (2002).Developing spelling and phonemic awareness in kindergarten. Unpublished master's thesis West Washington University Bellingham, Washington.

Ibrahim, B. \& Baba, W.(2008).Elements of measurement evaluation and statistics. Minna: Diamond Printers.

Karthigeyen, K. \& Nirmale, K. (2012).Academic achievement in English; an analysis through gender lens. Journals of Education Studies (2), I, 144-15.]

Kodae, H. \& Laohawiriyanon, S. (2011). Effect of intensive phonics instruction on reading and spelling attainment of that grade 5 learners with reading difficulties. A paper presented at the $3^{\text {rd }}$ International Conference on Humanities and Social Sciences, Department of Language and Linguistics. Prince of Sogkla University, Thailand.

Kutigi, A., Gambari, A.I. \& Gana, E. S. (2010). Effect of digital audio instructional package on the performance of Senior Secondary School Student in Oral English in Minna, Nigeria. Journal of Arts and Education, 4(2), 134-145.

Mostafa, R.R. (2019).The Impact of EFL Teachers' Assessment Literacy on Their Assessment Efficiency in Classroom Britain International of Humanities and Social Sciences. https://doi.org/10.33258/biolae.v1i1.14

Nwobia, A. (2007). Gender and secondary school students' performance in English language in Isoko, Delta State, Nigeria. Retrieved from: http://www.doublegist.com/student.performance

Ogunbanwo, R.A. (2014). Analysis of students' performance in West Africa Senior Certificate Examination in Boarding and Day Secondary Schools in Kano metropolis. An unpublished master's thesis, Department of Arts Education, Ahmadu Bello University, Zaria.

Ogunwole, O. (2014). Relative effects of co-operative and skeleton instruction on secondary school students performance in writing in Kwara State, Nigeria. Unpublished master's thesis Department of Arts Education University of Ilorin.

Omojuwa,E. (2014). WAEC results mass failure: Our collective disgrace and the way forward. Retrieved from: www.omojuwa. com/201/08/WEAC result.ma.

Parly, C. (1972). Native- live communication. London: Longman.

Tesfaye, B. B. and Desalegn, Y. U. (2019). An Exploration into Teachers' Perceptions towards the Challenges of Teaching Reading Skills using Communicative Language Teaching Approach: Focus on Wolaita Sodo Preparatory School. Britain International of Humanities and Social Sciences. https://doi.org/10.33258/biolae.v1i1. 